Conference Report, National Cystic Fibrosis Research Foundation, Galveston, Texas, October, 1973.

33. Takahama, M., and Barka, T.: Electron microscopic alterations of submaxillary gland produced by isoproterenol. J. Ultrastruct. Res., 17: 452 (1967).

34. Wilcken, D. E. L., Brender, D., Shorey, C. D., and MacDonald, G. J.: Reserpine: Effect on structure of heart muscle. Science, 157: 1332 (1967).

35. Reserpine, Vitarine Co., New York, N. Y.

36. Clay Adams PE 10, Clay Adams, A Division of Beeton, Dickinson Co., Parsippony, N. J.

37. St. Louis, Mo.

38. Instrumentation Laboratories, Lexington, Mass.

39. Corning Scientific Instruments, Medfield, Mass.

Copyright $\odot 1975$ International Pediatric Research Foundation, Inc.
40. Ismelin, Ciba Pharmaceutical Co., Summit, N. J.

41. Obtained from Carolina Supply Co., Burlington, N. C.

42. The authors wish to express their appreciation to Mr. Douglas Wood for this help in treating the animals and in performing experiments.

43. Dr. J. R. Martinez was recipient of a Research Scholar Award from the National Cystic Fibrosis Research Foundation.

44. This research was supported by a grant from the National Cystic Fibrosis Research Foundation, Atlanta, Georgia.

45. Requests for reprints should be addressed to: J. R. Martinez, M.D., Department of Child Health, University of Missouri Medical Center, N712 Medical Sciences Building, Columbia, Mo. 65201 (USA).

46. Accepted for publication November 20, 1974.

Printed in US.A.

Pediat. Res. 9: 475-480 (1975)

Arylsulfatase B lysosomal disorders
Maroteaux-Lamy syndrome mucopolysaccharidosis

\title{
Arylsulfatase B Deficiency in Maroteaux-Lamy Syndrome: Cellular Studies and Carrier Identification
}

\author{
NICHOLAS G. BERATIS, (36) BRYAN M. TURNER, ROBERTA WEISS, AND KURT HIRSCHHORN \\ Division of Medical Genetics, Department of Pediatrics, Mount Sinai School of Medicine of the City University of \\ New York, New York, New York, USA
}

\section{Extract}

Arylsulfatase B activity was studied in peripheral leukocytes obtained from 11 normal subjects, 2 obligate heterozygotes for Maroteaux-Lamy syndrome (MLS), and 1 homozygote for MLS. The activity (mean $\pm \mathrm{SD}$ ) was $113.7 \pm 36.2$ (range $57.4-181.8)$, 31.0 (25.7-34.5), and $5.0 \mathrm{nmol}$ 4-nitrocatechol $/ \mathrm{mg} \mathrm{protein} / \mathrm{hr}$, respectively. Although overlap occurred on two occasions between adjacent groups on single enzyme determinations, no overlap was observed between normal subjects, heterozygotes, and the homozygote when the mean activities of replicate assays performed were considered. In two normal siblings of the patient, sibling $l$ and sibling 2, the activity was $\mathbf{5 0 . 1}$ and $\mathbf{1 0 6 . 3}$, respectively. Arylsulfatase $B$ activity in cultured skin fibroblasts derived from 14 normal subjects, the 2 obligate heterozygotes for MLS, and the patient was $145.2 \pm 4.6(82.7-178.7), 58.5(49.3-67.6)$, and 7.0, respectively. Occasional overlap between normal subjects and heterozygotes again occurred with single enzyme determinations, but there was no overlap between the mean values of replicate assays performed on each case. Sibling 1 and sibling 2 showed activity of 51.0 and 96.0, respectively, confirming the leukocytes. Arylsulfatase $B$ activity in cultured skin fibroblasts of 11 patients with 7 other inborn errors of metabolism, including patients with Hurler's syndrome, Hunter's syndrome, and metachromatic leukodystrophy was within normal range. The lysosomal enzymes arylsulfatase $A$ (EC. 3.1.6.1), $\alpha$-D-galatosidase (EC. 3.2.1.22), $\alpha$-glucosidase (EC. 3.2.1.20), $\alpha$ L-iduronidase (EC. 3.2.1.76), $\alpha$-D-mannosidase (EC. 3.2.1.24), $\alpha$-L-fucosidase (EC. 3.2.1.51), $\beta$-D-galactosidase (EC. 3.2.1.23),
$\beta$-D-glucosidase (EC. 3.2.1.21), and $\beta$-D-glucuronidase (EC. 3.2.1.31) were normal in cultured skin fibroblasts of the patient with MLS. No arylsulfatase B activity was detected in a long term lymphoid cell line established from the patient with MLS. The arylsulfatase B activity in 10 normal lymphoid cell lines was $25.2 \pm 5.6$ with a range of 15.8-31.8. In cultured amniotic fluid cells from 10 normal pregnancies the arylsulfatase $B$ activity was $203.2 \pm 49.9$, with a range of 136.3-302.7. The findings indicate that peripheral leukocytes, cultured skin fibroblasts, and long term lymphoid cell lines can be used for the diagnosis of MLS, and that carrier detection is possible. Also the finding of arylsulfatase B activity in cultured amniotic fluid cells suggests that prenatal diagnosis of MLS is feasible.

\section{Speculation}

Deficiency of arylsulfatase $B$ is the basic metabolic defect in Maroteaux-Lamy syndrome. This enzyme probably catalyzes the cleavage of sulfate from the sulfated $\mathrm{N}$-acetylgalatosamine contained in dermatan sulfate. Its deficiency would result in tissue accumulation and urinary excretion of this mucopolysaccharide.

The Maroteaux-Lamy syndrome, first described in 1963 (16), is characterized by growth deficiency, coarse facies, corneal opacities, dysostosis multiplex, hepatosplenomegaly, cardiac valvular disease, normal or near normal intelligence, and an autosomal recessive mode of inheritance (17). There is increased urinary 
excretion of acid mucopolysaccharides, $70-95 \%$ of which is dermatan sulfate. Barton and Neufeld (1) have identified in the urine of normal subjects a specific factor that corrects the metabolic defect in cultured skin fibroblasts derived from patients with MLS. This factor was barely detectable in the medium of normal cultured skin fibroblasts. It has been reported that the activity of 12 lysosomal enzymes was normal in a patient with MLS, but the enzymes studied were not specified, except for $\alpha$-arabinosidase and $\beta$-galactosidase, which were in the lower range of normal values (22).

Stumpf and Austin (23) originally observed deficiency of arylsulfatase B in the liver of a patient with MLS. Later Stumpf et al. (24) described deficiency of arylsulfatase B in the liver, kidney, spleen, and brain of patients with MLS. They also reported deficiency of arylsulfatase $\mathrm{B}$ in cultured skin fibroblasts derived from a patient with MLS, but the enzymatic activities in the patient and control subjects were not specified. Arylsulfatase B activity of about $10 \%$ of that in normal subjects has recently been observed in cultured skin fibroblasts obtained from patients with MLS by Fluharty et al. (9).

We have found deficiency of arylsulfatase B activity in peripheral leukocytes, cultured skin fibroblasts, and a lymphoid cell line derived from a patient with MLS and have been able to identify the carrier state of the disease in fresh leukocytes and cultured skin fibroblasts.

\section{MATERIALS AND METHODS}

The patient, a female, JT260569 (i.e., born May 26, 1969) had normal psychomotor development. Kyphosis and prominent forehead were first noted at the age of 2 years. At the age of 4.5 years her height was below the 3 rd percentile, she had coarse facies, prominent forehead, corneal opacities, lumbar kyphosis, stiff joints, umbilical hernia, mild hepatosplenomegaly, and dysostosis multiplex. Figure 1 shows the patient at the age of 3.5 years. The total amount of acid mucopolysaccharides in the urine at the age of 2.5 years was $12.9 \mathrm{mg}$, more than $90 \%$ of which was dermatan sulfate (26).

\section{PERIPHERAL LEUKOCYTES}

Heparinized blood was obtained from the patient, the patient's parents, and two siblings, and from 11 normal donors. Five parts of blood were mixed with 1 part of $6 \%$ dextran and the erythrocytes were allowed to settle for $30 \mathrm{~min}$. The supernatant leukocyte-rich fraction was centrifuged and for complete removal of erythrocytes the resulting pellet was resuspended in $0.5 \mathrm{ml}$ normal saline and 2 $\mathrm{ml} 0.83 \% \quad \mathrm{NH}_{4} \mathrm{Cl}$. After $5 \mathrm{~min}$ at room temperature the cell suspension was centrifuged and, in cases where erythrocytes were still present in the pellet, the above procedure was repeated. Erythrocyte-free leukocytes were washed three times with normal saline and cells were stored at $-80^{\circ}$ until enzyme determinations were performed.

\section{CULTURED SKIN FIBROBLASTS, CULTURED AMNIOTIC FLUID} CELLS, AND LYMPHOID CELL LINES

Skin biopsy was obtained from the inner surface of the forearm of the patient, the patient's parents, 2 phenotypically normal siblings, and 14 normal subjects. Skin fibroblasts grown from the biopsy tissue were cultivated in Roswell Park Memorial Institute (RPMI) 1640 medium supplemented with $20 \%$ fetal calf serum (27), $1 \% 200 \mathrm{mM} \mathrm{L-glutamine,} 100 \mathrm{U} / \mathrm{ml}$ penicillin, and 100 $\mu \mathrm{g} / \mathrm{ml}$ streptomycin (28).

Amniotic fluid was obtained from normal pregnancies by transabdominal amniocentesis between the 16th and 19th week of gestational age. Amniotic fluid cells were cultured in RPMI 1640 medium supplemented with $30 \%$ fetal calf serum L-glutamine and antibiotics.

After the growth of a sufficient number of cells, cultures were passed in $75 \mathrm{~cm}^{2}$ flasks (29) and kept in an atmosphere of $10 \% \mathrm{CO}_{2}$ in air. Cultures were fed regularly twice a week. All cells used in
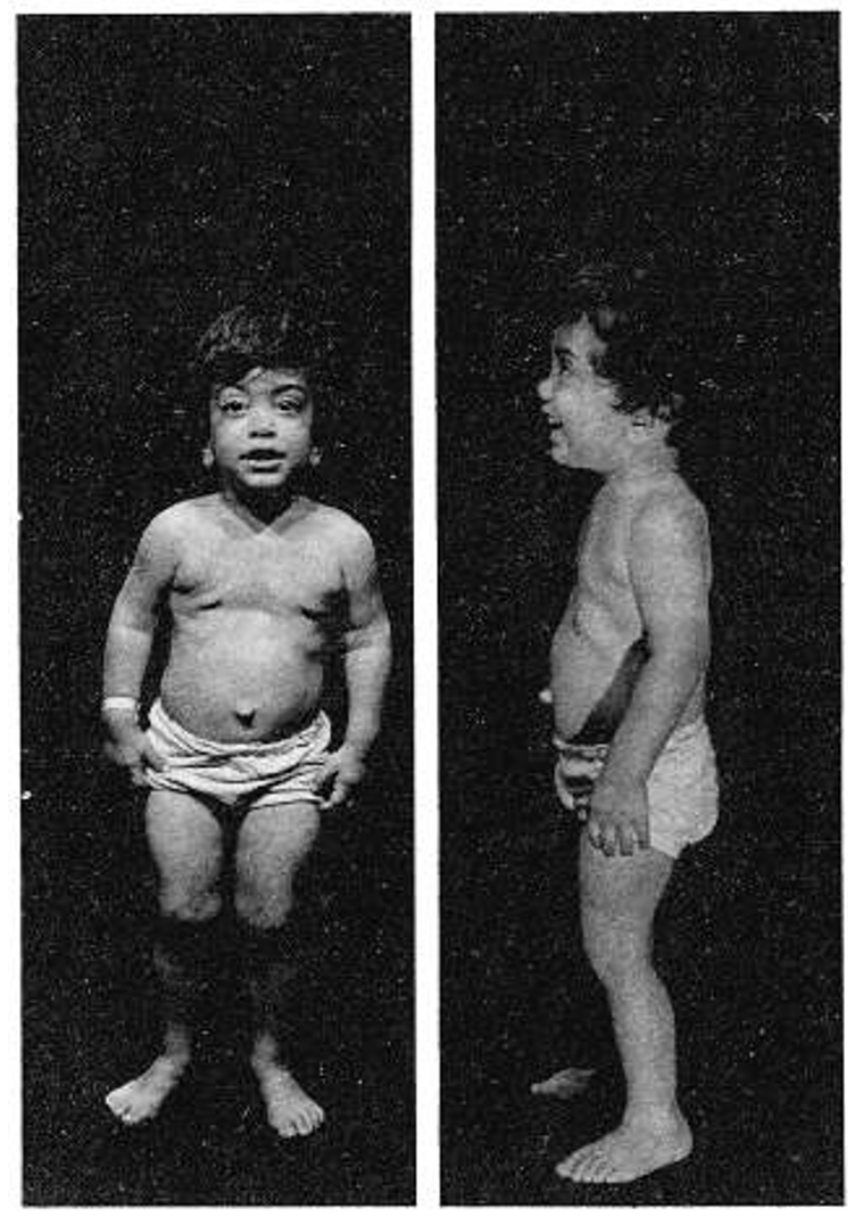

Fig. 1. The patient at the age of 3.5 years old.

enzymatic assays were derived from cultures in the early confluent stage, between the third and eighth subculture for skin fibroblasts and third and fifth passage for amniotic fluid cells. Cells were fed and were harvested $24 \mathrm{hr}$ later after a 1 -min exposure to $0.25 \%$ trypsin and subsequently to $0.02 \%$ sodium ethylenediaminetetraacetic acid in isotonic saline for $20 \mathrm{~min}$. Cells were washed three times and stored at $-80^{\circ}$. For the culture cycle experiment normal skin fibroblasts were grown to confluence and subsequently trypsinized and subcultured into multiple culture flasks. Every 2 days thereafter, up to the 10th day from the trypsinization, cells were harvested for enzyme determinations. Cells grew logarithmically from days $I$ through 5 , when they reached the stationary phase.

Cultured skin fibroblasts of the patient were examined by Dr. Elizabeth F. Neufeld from the National Institutes of Health and demonstrated excessive accumulation of ${ }^{35} \mathrm{SO}_{4}$-mucopolysaccharides. The metabolic defect was corrected with addition to the culture medium of the Maroteaux-Lamy factor.

Ten long term lymphoid cell lines established from normal donors, one line derived from the patient with MLS, and five lines derived from patients with other inborn errors of metabolism were used in the study. Lines were established, using a technique which we described earlier (4), that combines stimulation of peripheral leukocytes with phytohemagglutinin and incubation with EpsteinBarr virus or phytohemagglutinin stimulation alone (5). The lymphoid lines were fed with the same medium as cultured skin fibroblasts. Twenty-four hours before harvesting, lines were fed with fresh medium. The lymphoid cells were washed three times with isotonic saline and stored at $-80^{\circ}$

Cells were lysed in distilled water by eight cycles of rapid freezing and thawing. The lysates were centrifuged at $1,800 \times g$ for $5 \mathrm{~min}$ and the supernatant fractions were used for enzymatic determinations. 


\section{ENZYME ASSAYS}

Enzyme activities of arylsulfatase $A$ and $B$ were determined using $p$-nitrocatechol sulfate as substrate. $\alpha$-L-Iduronidase was measured using phenyl- $\alpha$-L-iduronide (30). Other enzymatic activities were determined utilizing either the $p$-nitrophenyl or the 4-methylumbelliferyl substrate derivatives. Substrates were supplied by Sigma Chemical Co. (31), except 4-methylumbelliferyl$\alpha$-D-mannoside, which was obtained from Koch-Light Laboratories (32).

Arylsulfatase A activity was determined in cell lysates by the method of Baum et al. (2), as adapted for peripheral leukocytes (20) and cultured skin fibroblasts (13), except that a shorter incubation period of $30 \mathrm{~min}$ was used. In peripheral leukocytes and lymphoid lines excess protein was removed from the final digest by heating in boiling water and by centrifugation (3).

Arylsulfatase B activity in peripheral leukocytes, cultured skin fibroblasts, and cultured amniotic fluid cells was measured by incubating $100 \mu \mathrm{l}$ of cell lysate (normal leukocytes, $175-330 \mu \mathrm{g}$ protein/tube; leukocytes homozygous and heterozygous for MLS, 390-800 $\mu \mathrm{g}$ protein; normal fibroblasts, $150-245 \mu \mathrm{g}$ protein; fibroblasts homozygous and heterozygous for MLS, $300-380 \mu \mathrm{g}$ protein; and $230-290 \mu \mathrm{g}$ amniotic fluid cell protein) with $400 \mu \mathrm{l}$ $0.0625 \mathrm{M} p$-nitrocatechol sulfate in $0.5 \mathrm{M}$ acetate buffer containing $10^{-2} \mathrm{M}$ barium acetate, $\mathrm{pH} 6.0$. The reaction was incubated at $37^{\circ}$ and after 30 and $90 \mathrm{~min}, 160 \mu$ digest were transferred to tubes containing $160 \mu 11 \mathrm{~N} \mathrm{NaOH}$. In lymphoid lines, 525-975 $\mu \mathrm{g}$ protein/tube were used and excess protein was removed by heating the final digests and the blank in boiling water for $90 \mathrm{sec}$ and centrifuging at $1,800 \times g$. The activities at 30 and $90 \mathrm{~min}$, after taking account of contributions from the blank, were used as described by Baum et al. (2) to estimate the contribution by arylsulfatase $\mathrm{A}$. The difference is expressed as arylsulfatase B activity. The amount of 4-nitrocatechol released was linear between 140 and $800 \mu \mathrm{g}$ leukocyte protein/tube, $140-380 \mu \mathrm{g}$ fibroblast protein/tube, and $400-1,100 \mu \mathrm{g}$ lymphoid cell line protein/tube. Decreased specific activities were obtained when lower protein concentrations were used.

Acid $\alpha$-glucosidase activity was measured in cell lysates using maltose as substrate by a modification of the method of Nitowsky and Grunfeld (19). $\alpha$-Galactosidase activity was determined colorimetrically in lysates by the method of Kint (14) using $p$-nitrophenyl- $\alpha$-D-galactoside. $\alpha$-L-Iduronidase was determined in fibroblast homogenates as previously described by Hall and Neufeld (11). $\alpha$-L-Fucosidase activity was measured in fibroblast lysates by a modification of the method of Zielke et al. (25). The concentration of $p$-nitrophenyl- $\alpha$-L-fucoside in the reaction mixture was increased to $3 \mathrm{mM}$, and the incubation time was reduced to $2 \mathrm{hr}$. $\alpha$-D-Mannosidase activity was estimated in lysates with 4methylumbelliferyl- $\alpha$-D-mannoside at $\mathrm{pH}$ 4.4. $\beta$-Galactosidase activity was measured in fibroblast lysates with 4-methylumbelliferyl- $\beta$-D-galactoside according to the method of $\mathrm{Ho}$ et al. (12). $\beta$-Glucosidase was measured in fibroblast homogenates with 4-methylumbelliferyl- $\beta$-D-glucoside (12), except that Triton X-100 was not added. $\beta$-Glucuronidase activity was determined by using $p$-nitrophenyl- $\beta$-D-glucuronide as previously described (10) except that a shorter incubation period of $2 \mathrm{hr}$ was used. Protein was measured by the method of Lowry et al. (15). All assays were carried out in duplicate. The released 4-nitrocatechol and $p$-nitrophenol were measured against a blank at 515 and 420 $\mathrm{nm}$, respectively. The fluorescence of 4-methylumbelliferone was measured at $450 \mathrm{~nm}$ after excitation at $360 \mathrm{~nm}$. Student's $t$ test was employed for the statistical analysis of the data.

\section{RESULTS}

\section{PERIPHERAL LEUKOCYTES}

Table 1 lists the activities of arylsulfatase $A$ and $B$ in peripheral leukocytes obtained from 11 normal donors, 2 obligate heterozygotes for MLS, 1 homozygote for MLS, and 2 potential heterozygotes for the disease. The activity of arylsulfatase $B($ mean $\pm S D$ ) in the normal, heterozygous, and homozygous leukocytes was $113.7 \pm 36.2,31.0$, and $5.2 \mathrm{nmol} 4$-nitrocatechol released $/ \mathrm{mg}$ soluble protein $/ \mathrm{hr}$, respectively. In one of the 19 keukocyte lysates of the 11 normal doncrs studied, the enzyme activity fell within the heterozygous values. Also in 1 out of 12 lysates studied from the 2 obligate heterozygotes the enzyme activity overlapped with a high value obtained in a lysate of the patient's leukocytes. In two other cell lysates from the patient, no arylsulfatase B activity was detected.

\section{CULTURED SKIN FIBROBLASTS, CULTURED AMNIOTIC FLUID} CELLS, AND LYMPHOID CELL. LINES

Table 2 lists the activity of arylsulfatase $B$ in cultured skin fibroblasts derived from 14 normal donors, 2 obligate heterozygotes for MLS, 1 homozygote for MLS, 2 siblings of the patient, and 11 patients with seven other inborn errors of metabolism. Table 3 lists the specific activities of nine other lysosomal enzymes in cultured skin fibroblasts of the above subjects. The values in the patient's skin fibroblasts fell within the control range for each enzyme. No deficiency of arylsulfatase B was detected in the fibroblasts of the other inborn errors of metabolism studied. Mixing experiments between lysates of normal and deficient cultured skin fibroblasts gave the expected enzymatic activities.

In the culture cycle experiment the arylsulfatase $B$ activity fell to the lowest level on the 4th day after trypsinization and thereafter it increased steadily. On the 10 th day the activity was almost double

Table 1. Arylsulfatase $A$ and $B$ activity in peripheral leukocytes of 10 normal subjects, 2 obligate heterozygotes, 1 homozvgote, and 2 potential heterozygotes for Maroteaux-Lamy syndrome ${ }^{1}$

\begin{tabular}{|c|c|c|c|c|c|c|}
\hline \multirow[b]{2}{*}{ Subject } & \multirow[b]{2}{*}{$\begin{array}{c}\text { No. } \\
\text { studied }\end{array}$} & \multirow[b]{2}{*}{$\begin{array}{c}\text { No. of } \\
\text { preparations }\end{array}$} & \multicolumn{3}{|c|}{ Arylsulfatase B } & \multirow[b]{2}{*}{$\begin{array}{c}\text { Arylsulfa- } \\
\text { tase A (mean) }\end{array}$} \\
\hline & & & Mean & $\begin{array}{c}\text { Range of mean } \\
\text { values }\end{array}$ & $\begin{array}{c}\text { Range of indivi- } \\
\text { dual assays }\end{array}$ & \\
\hline Normal & 11 & 19 & $113.7 \pm 36.2^{2}$ & $57.4-181.8$ & $21.4-181.8$ & $391.0 \pm 96.0^{2}$ \\
\hline Obligate heterozygotes & 2 & 12 & 31.0 & $25.7-34.5$ & $12.8-43.3$ & 393.9 \\
\hline Father & 1 & 6 & 25.7 & & $12.8-43.3$ & 425.8 \\
\hline Mother & 1 & 6 & 34.5 & & $31.0-42.6$ & 359.1 \\
\hline Homozygote & 1 & 3 & 5.2 & & $0.0 \cdots 15.5$ & 400.0 \\
\hline Potential heterozygotes & 2 & 5 & & & & \\
\hline Sibling 1 & 1 & 2 & 50.1 & & $45.3-54.9$ & 497.4 \\
\hline Sibling 2 & I & 3 & 106.3 & & $56.2-181.0$ & 432.7 \\
\hline
\end{tabular}

\footnotetext{
${ }^{1}$ Enzyme activity is expressed in nanomoles of 4-nitrocatechol per milligram of protein per hour. The difference of the enzyme activities of all assays
} between normal subjects and obligate heterozygotes is highly significant $(\mathrm{t}=7.0618 ; P<0.0005)$.

${ }^{2}$ Mean $\pm \mathrm{SD}$. 
Table 2. Arylsulfatase B activity in cultured skin fibroblasts of 14 normal donors, 2 obligate heterozygotes, 1 homozygote, and 2 potential heterozygotes for Maroteaux-Lamy syndrome, and 11 patients with other inborn errors of metabolism ${ }^{1}$

\begin{tabular}{|c|c|c|c|c|c|}
\hline \multirow[b]{2}{*}{ Subject } & \multirow[b]{2}{*}{$\begin{array}{l}\text { No. } \\
\text { studied }\end{array}$} & \multirow[b]{2}{*}{$\begin{array}{c}\text { No. of } \\
\text { preparations }\end{array}$} & \multicolumn{3}{|c|}{ Enzyme activity } \\
\hline & & & Mean & $\begin{array}{c}\text { Range of mean } \\
\text { values }\end{array}$ & $\begin{array}{c}\text { Range of individual } \\
\text { assays }\end{array}$ \\
\hline Normal & 14 & 42 & $145.2 \pm 41.6^{2}$ & $82.7-178.7$ & $25.6-377.3$ \\
\hline Obligate heterozygotes & 2 & 12 & 58.5 & $49.3-67.6$ & $19.7-85.0$ \\
\hline Father & 1 & 6 & 67.6 & & $53.0-81.3$ \\
\hline Mother & 1 & 6 & 49.3 & & $19.7-85.0$ \\
\hline Homozygote & 1 & 6 & 7.0 & & $0.0-16.6$ \\
\hline Potential heterozygotes & 2 & 12 & & & \\
\hline Sibling $l$ & 1 & 6 & 51.0 & & $17.2-81.0$ \\
\hline Sibling 2 & 1 & 6 & 96.6 & & $50.0-130.4$ \\
\hline Fucosidosis & 2 & 6 & 128.2 & $121.4-135.1$ & $96.0-157.3$ \\
\hline Galactosemia & 2 & 6 & 139.7 & $139.6-139.8$ & $76.4-261.3$ \\
\hline Gaucher's disease & 3 & 8 & 117.1 & $107.7-114.5$ & $38.9-242.7$ \\
\hline Hunter's syndrome & 1 & 3 & 107.7 & & $96.4-116.4$ \\
\hline Hurler's syndrome & 1 & 3 & 118.4 & & $40.8-179.9$ \\
\hline Metachromatic leukodystrophy & 1 & 4 & 93.4 & & $42.0-126.0$ \\
\hline Pompe's disease & 1 & 3 & 78.1 & & $32.9-121.5$ \\
\hline
\end{tabular}

1 Enzyme activity is expressed in nanomoles of 4-nitrocatechol per milligram of protein per hour. The difference of the enzyme activities of all assays between normal subjects and obligate heterozygotes, as well as heterozygotes and homozygotes are highly significant $(\mathrm{t}=6.3979, P<0.0005$, and $\mathrm{t}=$ $7.8265, P<0.0005$, respectively).

${ }^{2}$ Mean \pm SD.

Table 3. Activity of nine lysosomal enzymes in cultured skin fibroblasts derived from 14 normal subjects, a patient with Maroteaux-Lamy syndrome $(M L S)$, the patient's parents and siblings, and 11 patients with seven various inborn errors of metabolism ${ }^{1}$

\begin{tabular}{|c|c|c|c|c|c|c|c|c|c|}
\hline Subjects (No.) & $\begin{array}{l}\text { Acid } \alpha^{-} \\
\text {gluco- } \\
\text { sidase }^{2}\end{array}$ & $\begin{array}{c}\alpha-\mathrm{D}- \\
\text { Galac- } \\
\text { tosidase }^{3}\end{array}$ & $\begin{array}{c}\alpha-\mathrm{L}- \\
\text { Iduro- } \\
\text { nidase }^{4}\end{array}$ & $\begin{array}{c}\alpha-\mathrm{D}- \\
\text { Man- } \\
\text { nosidase }^{5}\end{array}$ & $\begin{array}{c}\alpha-\mathrm{L}- \\
\text { Fuco- } \\
\text { sidase }^{3}\end{array}$ & $\begin{array}{l}\text { Arylsul- } \\
\text { fatase } A^{6}\end{array}$ & $\begin{array}{c}\beta-\mathrm{D}- \\
\text { Galac- } \\
\text { tosidase }^{5}\end{array}$ & $\begin{array}{c}\beta \text {-D- } \\
\text { Gluco- } \\
\text { sidase }^{5}\end{array}$ & $\left\{\begin{array}{c}\beta-D- \\
\text { Glucu- } \\
\text { ronidase }^{3}\end{array}\right.$ \\
\hline \multirow[t]{4}{*}{ Normal (14) } & 468.9 & 172.1 & 348.3 & 810.6 & 74.8 & $1,179.4$ & $13,032.0$ & $1,639.1$ & 237.8 \\
\hline & \pm 169.1 & \pm 51.5 & \pm 101.4 & \pm 203.1 & \pm 34.2 & $\pm \dot{473.4}$ & $\pm 3,495.7$ & \pm 484.4 & \pm 66.8 \\
\hline & $(240.6-$ & (117.7一 & $(222.1-$ & $(521.9-$ & $(37.9-$ & $(639.4-$ & $(9,082.7-$ & $(969.0-$ & $(157.9-$ \\
\hline & $758.5)$ & 261.7) & 462.3) & $1,001.5)$ & $176.4)$ & $2,071.4)$ & $19,681.5)$ & $2,931.0)$ & $360.1)$ \\
\hline $\operatorname{MLS}(1)$ & 374.4 & 141.2 & 444.7 & 801.1 & 90.2 & $1,310.5$ & $11,988.6$ & $1,372.3$ & 277.4 \\
\hline Heterozygotes for MLS (2) & 351.6 & 134.7 & 266.9 & 774.5 & 89.5 & $1,176.4$ & $11,625.9$ & $1,901.8$ & 255.1 \\
\hline Sibling 1 & 281.8 & 241.1 & NT & 566.9 & 51.7 & $1,171.8$ & $12,823.3$ & $1,830.6$ & 122.2 \\
\hline Sibling 2 & 286.8 & 186.4 & NT & 876.9 & 54.1 & 982.4 & $10,644.7$ & $1,564.5$ & 126.3 \\
\hline Fucosidosis (2) & 477.1 & 224.6 & 506.3 & $1,573.1$ & 0.05 & $1,382.6$ & $18,134.2$ & $1,444.0$ & 114.1 \\
\hline Galactosemia (2) & 247.3 & 183.9 & 391.1 & 945.2 & 65.6 & 752.4 & $9,435.8$ & $2,065.0$ & 93.8 \\
\hline Gaucher's disease (3) & 359.6 & 241.8 & 534.8 & 662.6 & 136.3 & $1,259.2$ & $15,897.9$ & 147.7 & 193.1 \\
\hline Hunter's syndrome (1) & 241.6 & 205.0 & 604.3 & 551.3 & 105.3 & 738.1 & $14,303.8$ & $1,717.7$ & 128.6 \\
\hline Hurler's syndrome (1) & 651.5 & 295.6 & 0.0 & 796.7 & 50.0 & $1,240.5$ & $18,766.2$ & $1,558.1$ & 242.6 \\
\hline Metachromatic leukodystrophy (1) & 147.2 & 280.9 & 374.1 & 569.8 & 79.6 & 17.4 & $10,502.1$ & $1,476.2$ & 125.2 \\
\hline Pompe's disease (1) & 0.0 & 167.3 & 386.9 & 896.9 & 59.9 & 642.8 & $16,274.5$ & $1,232.5$ & 203.7 \\
\hline
\end{tabular}

${ }^{1}$ Activity of normal subjects shows the mean \pm SD with the observed range in parenthesis. NT: not tested.

${ }^{2}$ Micrograms of glucose released per milligram of protein per hour.

${ }^{3}$ Nanomoles of $p$-nitrophenol per milligram of protein per hour.

${ }^{4}$ Nanomoles of phenol per milligram of protein per $18 \mathrm{hr}$.

${ }^{5}$ Picomoles of 4-methylumbelliferone per milligram of protein per minute.

${ }^{6}$ Nanomoles of 4-nitrocatechol per milligram of protein per hour.

that observed on the 4 th day. The $\alpha$-L-fucosidase studied in the same cell lysates as arylsulfatase B followed a different pattern of activity (Fig. 2).

In Table 4 are listed the activities of arylsulfatase A and B in 10 lymphoid lines established from normal donors, the line derived from the patient with MLS, and 5 lines established from patients with other inborn errors of metabolism. No arylsulfatase B activity was detected in the Maroteaux-Lamy lymphoid line.

In cultured amniotic fluid cells obtained from 10 normal pregnancies the mean arylsulfatase B activity was $203.2 \pm 49.9$, with a range of 136.3-302.7.

\section{DISCUSSION}

Our results demonstrate deficiency of arylsulfatase B activity in fresh peripheral leukocytes, cultured skin fibroblasts, and a long term lymphoid cell line derived from a documented case of MLS. The activity in the patient's leukocytes and skin fibroblasts was 4.6 and $4.8 \%$ of the activity in the normal cells, respectively, whereas no activity was detected in the Maroteaux-Lamy lymphoid line. The activity in leukocytes and cultured skin fibroblasts obtained from the patient's parents was 26.5 and $40.3 \%$ of the control values, respectively. In occasional single determinations overlap 
Table 4. Arylsulfatase $A$ and $B$ activity in lymphoid cell lines established from normal donors, from a patient with Maroteaux-Lamy syndrome, and from patients with other inborn errors of metabolism ${ }^{2}$

\begin{tabular}{|c|c|c|c|c|c|c|}
\hline \multirow[b]{2}{*}{ Lines } & \multirow{2}{*}{$\begin{array}{l}\text { No. } \\
\text { studied }\end{array}$} & \multirow{2}{*}{$\begin{array}{c}\text { No. of } \\
\text { preparations }\end{array}$} & \multicolumn{2}{|c|}{ Arylsulfatase B } & \multicolumn{2}{|c|}{ Arylsulfatase $\mathrm{A}$} \\
\hline & & & Mean & Range & Mean & Range \\
\hline Normal & 10 & 15 & $25.2 \pm 5.6^{2}$ & $15.8-31.8$ & $50.0 \pm 14.1^{2}$ & $34.2-79.8$ \\
\hline Maroteaux-Lamy & 1 & 5 & 0.0 & 0.0 & 60.9 & $59.2-62.7$ \\
\hline Cystic fibrosis & 2 & 2 & 12.9 & $11.5-14.3$ & 47.8 & $44.2-51.4$ \\
\hline Fucosidosis & 1 & 2 & 17.6 & $14.7-20.5$ & 51.9 & $42.7-61.2$ \\
\hline Hurler's syndrome & 1 & 2 & 12.4 & $12.1-12.7$ & 53.2 & $38.4-68.1$ \\
\hline Metachromatic leukodystrophy & 1 & 2 & 29.8 & $26.1-33.5$ & 1.4 & $1.2-1.7$ \\
\hline
\end{tabular}

${ }^{1}$ Enzyme activity is expressed in nanomoles of 4-nitrocatechol per milligram of protein per hour.

${ }^{2}$ Mean \pm SD.

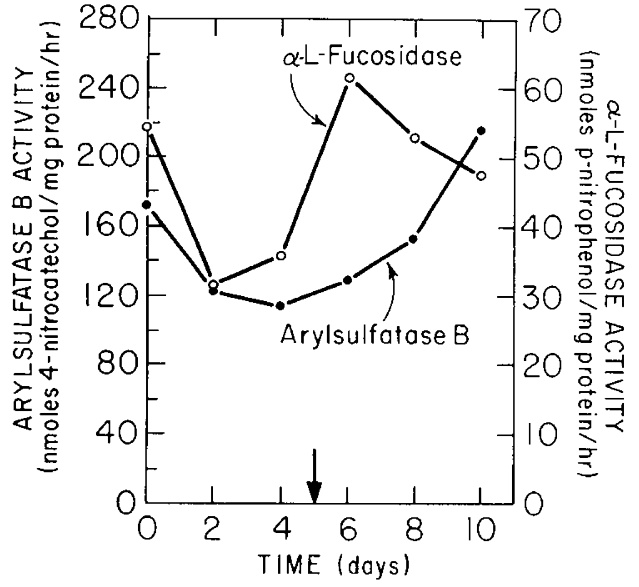

Fig. 2. Levels of specific activities of arylsulfatase $B$ and $\alpha$-L-fucosidase during the culture cycle of skin fibroblasts. Arrow shows end of growth phase and beginning of stationary phase.

between the enzyme activity of normal donors and heterozygotes was observed. This overlap could possibly be attributed to limitations of the assay system or changes in the culture conditions. Since care was taken to harvest the cells at the same growth phase and because similar variation in enzyme activity was also observed in some peripheral leukocyte assays, it seems likely that the variation is caused by technical difficulties inherent in the assay system. However, when the mean activities of the assays performed on each case were considered, a clear delineation between homozygotes, heterozygotes, and control subjects was obtained. It appears that for the reliable identification of the carrier state of MLS at least two peripheral leukocyte or cultured skin fibroblast lysates of a given individual should be studied.

One of the patient's siblings demonstrated arylsulfatase B activity within the normal range in both peripheral leukocytes and cultured skin fibroblasts, suggesting that she is homozygous for the wild type allele at the Maroteaux-Lamy locus. The other sibling showed, in peripheral leukocytes, $44.1 \%$ activity of the control values, that is, higher than $26.5 \%$ activity observed in the obligate heterozygote parents. Cultured skin fibroblasts of the same subject demonstrated arylsulfatase B activity well within the heterozygote range, suggesting that she is a carrier for MLS.

The drop of arylsulfatase B activity during the growth phase of the fibroblasts and subsequent increase of activity during confluence indicate that cultures should be stopped at the same growth phase. Since the growth rate of skin fibroblasts from different individuals varies considerably, cultures should be observed before harvesting.

The absence of arylsulfatase B activity demonstrated in a long term lymphoid line established from the patients with MLS indicates that the line maintained the genotype of the donor and that lymphoid lines can be used for the study of affected individuals. The apparent permanence and remarkable proliferative ability of the lymphoid lines make them excellent tools for detailed studies of the metabolic defect in MLS. Other metabolic disorders already detected in lines are the Lesch-Nyhan syndrome (6), metachromatic leukodystrophy (3), citrullinemia (21), cystic fibrosis (7), and homocystinuria (8).

The finding that arylsulfatase B activity is present in cultured amniotic fluid cells suggests that prenatal diagnosis of the MLS is feasible. Determination of the normal range of values in a sufficient number of control cultures and study of more than one preparation of the cultured amniotic fluid cells of the fetus at risk are indicated for the prenatal detection of the disease.

Presence of arylsulfatase B activity was demonstrated in cultured skin fibroblasts of seven other inborn errors of metabolism, including a patient with Hurler's and a patient with Hunter's syndrome. These findings indicate that arylsulfatase $B$ is not inhibited by the presence of dermatan sulfate. That the enzymatic deficiency is not caused by the presence of an inhibitor is also indicated from the findings of the mixing experiments.

The severe deficiency of arylsulfatase B activity in three different types of cells derived from the patient with MLS and the reduced enzymatic activity in leukocytes and cultured skin fibroblasts from heterozygotes indicate that deficiency of arylsulfatase $\mathrm{B}$ is the basic metabolic defect of this inborn error of mucopolysaccharide metabolism. This enzyme probably catalyzes the cleavage of sulfate from the sulfated $N$-acetylgalactosamine contained in dermatan sulfate.

Recently O'Brien et al. (19) reported deficiency of $\mathrm{N}$-acetylgalactosamine-4-sulfatase (EC. 3.1.6.*) in cultured skin fibroblasts obtained from two patients with MLS. However, two other patients with the clinical picture of MLS studied by O'Brien and Cantz demonstrated normal activity of this enzyme (unpublished data cited in Reference 19). This apparent contradiction may be due to heterogeneity already suggested on clinical evidence (21).

It appears that use of the artificial substrate $p$-nitrocatechol sulfate provides an easy method for the diagnosis of MLS in various cell types. Our findings also confirm the autosomal recessive mode of inheritance of MLS and indicate that carrier detection is possible.

\section{SUMMARY}

Arylsulfatase B deficiency was demonstrated in peripheral leukocytes, cultured skin fibroblasts, and a lymphoid line derived from a patient with MLS. The patient's parents demonstrated levels of arylsulfatase B that were intermediate between those found in the patient and those in control subjects. The activity (mean $\pm \mathrm{SD}$ ) in leukocytes from normal subjects, the patient's parents, and the patient was $113.7 \pm 36.2,31.0$, and $5.2 \mathrm{nmol}$ 4-nitrocatechol/mg protein/hr, respectively. In skin fibroblasts of the same subjects the activity was $145.2 \pm 41.6,58.5$, and 7.0, respectively. Nine other lysosomal enzymes were normal in skin fibroblasts of the patient. No arylsulfatase B activity was detected 
in a lymphoid line established from the patient with MLS. The arylsulfatase $B$ activity in cultured amniotic fluid cells from 10 normal pregnancies was $203.2 \pm 49.9$.

\section{REFERENCES}

1. Barton, R. W., and Neufeld, E. F.: A distinct biochemical deficit in the Maroteaux-Lamy syndrome (mucopolysaccharidosis VI). J. Pediat., 80: 114 (1972).

2. Baum, H., Dodgson, K. S., and Spencer, B.: The assay of arylsulfatases A and B in human urine. Clin. Chim. Acta, 4: 453 (1959).

3. Beratis, N. G., Danesino, C., and Hirschhorn, K.: Detection of homozygotes and heterozygotes for metachromatic leukodystrophy in lymphoid cell lines and peripheral leukocytes. Ann. Hum. Genet., 38: 485 (1975).

4. Beratis, N., and Hirschhorn, K.: Procedure for establishment of long-term lymphoid cell lines by using PHA and HLV. In: D. Bergsma; Long-term Lymphocyte Cultures in Human Genetics. Birth Defects: Original Article Series, Vol. 9, pp. 247-248. The National Foundation, USA, 1973.

5. Beratis, N. G., and Hirshhorn, K.: Establishment of long-term lymphoid cell lines. Mamm. Chrom. Newsl., 14: 114 (1973).

6. Choi, K. W., and Bloom, A. D.: Biochemically marked lymphoid lines: Establishment of Lesch-Nyhan cells. Science, 170: 89 (1970).

7. Conover, J. H. Beratis, N. G., Conod, E. J., Ainbender, E., and Hirschhorn, K.: Studies on ciliary dyskinesia factor in cystic fibrosis. Il. Short-term leukocyte cultures and long-term lymphoid lines. Pediat. Res., 7: 224 (1973).

8. Fleisher, L. D., Beratis, N. G., Tallan, H. H., Hirschhorn, K., and Gaull, G. E.: Homocystinuria due to cystathionine synthase (CS) deficiency: Investigations in cultured long-term lymphocytes, fetal skin fibroblasts and amniotic fluid cells (Abstract). Pediat. Res., 8: $388 / 144$ (1974)

9. Fluharty, A. L.. Stevens, R. L., Sanders, D. L., and Kihara, H.: Arylsulfatase B deficiency in Maroteaux-Lamy syndrome cultured fibroblasts. Biochem. Biophys. Res. Commun., 59: 455 (1974).

10. Glasser, J. H., and Sly, W. S.: $\beta$-Glucuronidase deficiency mucopolysaccharidosis: Methods for enzymatic diagnosis. J. Lab. Clin. Med., 82: 969 (1973).

11. Hall, C. W., and Neufeld, E. F.: $\alpha$-L-Iduronidase activity in cultured skin fibroblasts and amniotic fluid cells. Arch. Biochem. Biophys., 158: 817 (1973).

12. Ho, M. W., Seck, J., Schmidt, D., Veath. M. L., Johnson, W., Brady, R. O., and O'Brien, J. S.: Adult Gaucher's disease: Kindred studies and demonstration of a deficiency of acid $\beta$-glucosidase in cultured fibroblasts. Amer. J. Hum. Genet., 24: 37 (1972)

13. Kaback, M. M., and Howell, R. R.: Infantile metachromatic leukodystrophy: Heterozygote detection in skin fibroblasts and possible applications to intrauterine diagnosis. N. Engl. J. Med., 282: 1336 (1970).

14. Kint, J. A.: Fabry's disease: Alpha-galactosidase deficiency. Science, 167: 1268 $(1970)$.

Copyright (C) 1975 International Pediatric Research Foundation, Inc
15. Lowry, O. H., Rosebrough, N. J., Farr, A. L., and Randall, R. J.: Protein measurement with the Folin phenol reagent. J. Biol. Chem., 193: 265 (1951).

16. Maroteaux, P., Lévêque, B., Marie, J., and Lamy, M.: Une nouvelle dysostose avec élimination urinaire de chondroitine-sulfate B. Presse Méd., 71: 1849 (1963).

17. McKusick, V. A.: Hereditable disorders of connective tissue. In: V. A. McKusick: fourth edition, The C. V. Mosby Company, Saint Louis, 1972, pp. $611-627$.

18. Nitowsky, H. M., and Grunfeld, A.: Lysosomal $\alpha$-flucosidase in Type II glycogenosis; activity in leukocytes and cell cultures in relation to genotype. J. Lab. Clin. Med., 69: 472 (1967).

19. O'Brien, J., Cantz, M., and Spranger, J.: Maroteaux-Lamy disease (mucopolysaccharidosis VI), subtype A: Deficiency of a $N$-acetylgalatosamine-4-sulfatase. Biochem. Biophys. Res. Commun., 60: 1170 (1974).

20. Percy, A. K., and Brady, R. O.: Metachromatic leukodystrophy: Diagnosis with samples of venous blood. Science, 16I: 594 (1968).

21. Spector, E. B., and Bloom, A. D.: Citrullenimic lymphocytes in long-term culture. Pediat. Res., 7: 700 (1973).

22. Spranger, J. W., Koch, F., McKusick, V. A., Natzschka, J., Wiedemann, H.-R., and Zellweger, H.: Mucopolysaccharidosis VI (Maroteaux-Lamy's disease). Helv. Paediat. Acta, 25: 337 (1970)

23. Stumpf, D., and Austin, J.: An arylsulfatase B deficiency in a mucopolysaccharidosis (Abstract). Trans. Amer. Soc. Neurochem., 3: 125 (1972).

24. Stumpf, D. A., Austin, J. H., Crocker, A. C., and LaFrance, M.: Mucopolysaccharidosis Type VI (Maroteaux-Lamy syndrome). I. Sulfatase B deficiency in tissues. Amer. J. Dis. Child., 126: 747 (1973).

25. Zielke, K., Veath, M. L., and O'Brien, J. S.: Fucosidosis: deficiency of alpha-L-fucosidase in cultured skin fibroblasts. J. Exp. Med., 136: 197 (1972).

26. Courtesy of Dr. Ruben Matalon of the University of Chicago, Chicago, Ill.

27. Associated Biometric Systems, Inc., Buffalo, N Y.

28. Grand Island Biological Co., Grand Island, N.Y.

29. Faicon Plastics, Oxnard, Calif.

30. Kindly donated to us by Dr. Bernard Weissmann, under United States Public Health Service Contract NIH-NIAMDD 83-2205.

31. Sigma Chemical Co., Saint Louis, Mo.

32. Koch-Light Laboratories, Ltd., Colnbrook, Buckinghamshire, England.

33. This research was supported by United States Public Health Service Grant HD002552 and Genetics Center Grant GM 19443.

34. Dr. Kurt Hirschhorn is a Career Scientist of the Health Research Council of the City of New York (I-513).

35. The studies on human subjects were performed with their informed consent or, in the case of children, with the informed consent of their parents.

36. Requests for reprints should be addressed to: N. G. Beratis, M.D., Department of Pediatrics, Division of Medical Genetics, Mount Sinai School of Medicine of the City University of New York, N.Y. 10029 (USA).

37. Accepted for publication January 6, 1975.

Printed in U.S.A

Pediat. Res. 9: 480-483 (1975)

Bilirubin

glucaric acid glucuronic acid

\title{
Glucaric Acid Excretion as Index of Hepatic Glucuronidation in Neonates after Phenobarbital Treatment
}

\author{
EDMUND TALAFANT, ${ }^{(25)}$ ANNA HOŠKOV $\AA$, AND ANNA POJEROVÁ \\ Department of Medical Chemistry, First Pediatric Clinic, J. E. Purkyně University, and Neonatal Unit of the First \\ Municipal Hospital, Brno, Czechoslovakia
}

\section{Extract}

Urinary glucaric and glucuronic acid excretion was followed simultaneously with serum bilirubin levels in normal full term newborn boys treated with intramuscularly applied phenobarbital (10 $\mathrm{mg} / \mathrm{kg} / 24 \mathrm{hr}$ divided into 3 doses daily at 8 -hr intervals for 3 days for a total of 10 doses) and in a group of newborn boys treated with orally administered phenobarbital in tablet form on the same dosage schedule. Both groups were compared with a control group without treatment. Average serum bilirubin level on the 7 th day of life in the intramuscularly treated group $(3.2 \mathrm{mg} / 100 \mathrm{ml} \pm 0.46$ SEM) was lower than the serum bilirubin level on the same day in 